\title{
Demystifying Perceptual Learning Style Preferences of Vietnamese University Freshmen in English Academic Achievement
}

\author{
Tuan Van Vu \\ Hanoi Law University \\ 87 Nguyen Chi Thanh street, Dong Da district, Ha Noi city, Vietnam \\ https://orcid.org/0000-0002-3066-7338 \\ Dinh Ngoc Tran \\ Hanoi Law University \\ 87 Nguyen Chi Thanh street, Dong Da district, Ha Noi city, Vietnam \\ https://orcid.org/0000-0003-4868-4758
}

\begin{abstract}
Learning styles play an important role in teaching and learning, especially in second language acquisition. This study aims to investigate the perceptual language learning style preference of 385 first-year university students in Vietnam. Adapting Reid's (1984) learning style questionnaire is used as a data gathering tool in which it was responded and retrieved via students' emails incorporated with Google form. The results revealed that freshmen were active learners since they mostly belonged to 4 major learning styles, namely Tactile, Auditory, Group, and Kinesthetic learners, and 2 minor learning styles, i.e. Visual and Individual learners. In addition, the study did not find the differences between gender as well as major and non-major English students in comparison with learning styles. Besides, freshmen's English academic achievement was highly influenced by their learning styles. The research findings contribute resourceful references to the formation of stakeholders' policies on English language teaching and learning, teachers of English, and future studies.
\end{abstract}

Keywords: Major learning style; Minor learning style; Model; Second language acquisition

\section{Introduction}

In the educational setting, different learners have their own ways to acquire the second languages (L2), and the issue of learning style preferences (hereafter, LSP) has been investigated in a number of studies until now. Some learning style models have been proposed and widely acknowledged since 1970s (Dunn \& Dunn, 1978; Kolb, 1985; Reid, 1984; Fleming, 2001). These researchers categorized 
LSP into some specific styles. Since then, many studies have been carried out to find out the congruency between LSP and English language achievement (Afshara et al., 2015; Al-zayed, 2017; Gohar \& Sadeghi, 2014; Tabatabaeia \& Mashayekhi, 2013; Wilson, 2012). Other studies have investigated the influence of LSP on the academic achievement (Almigbal, 2015; Bhattacharyya \& Sarip, 2014; Khanum, 2014; Yee et al., 2015), and other influential fields as well.

Raising awareness about learners' LSP plays an important role in acquiring the second language (Sadeghiet al., 2012). Thus, motivating language learners is pertinent in the current language teaching and its associated learning environments. Besides, language teachers commonly blame their learners' academic weaknesses and/or poor performance for the learners' cognitive measures (i.e. intelligence and mental abilities), poor vocabulary knowledge, inability to listen well or reading disabilities, etc. while studying learners' individual differences have been paid little attention. In practice, different variables have caused many debates on how to assess learner's failure or success in academic performance (Furnham \& Monsen, 2009). Oxford (1989) claims that language learning styles and strategies are the most essential variables which strongly affect learners' performance in a second language. Language learning styles are considered as a valid psychological construct according to the notion which is put forward in a research in educational settings by Sim et al. (1989). Moreover, language learning styles are also one of the most important determinants of educational achievement. Obviously, some learners can still gain simple knowledge even if there is a mismatch between the learning materials and their learning styles, but they can learn better and faster if their learning resources are in accordance with their learning style strengths (Stevenson \& Dunn, 2001). Therefore, getting to know students' LSP helps teachers either design suitable learning materials to meet their students' demands, who possess different stylistic preferences or improve students' learning strategies.

With reference to the related studies, many studies have been conducted to investigate the influence of LSP towards the academic performance (Almigbal, 2015; Bogamuwa, 2017; Magdalena, 2015; Wilson, 2012; Ajideh et al., 2018), gender differences (Bidabadi \& Yamat, 2010; Dobson, 2010; Choudhary et al., 2011; Sarabi-Asiabar et al., 2014; Shuib \& Azizan, 2015), English language achievement (Afshara et al., 2015; Al-zayed, 2017; Gohar \& Sadeghi, 2014; Komlosi, 2018; Moo \& Eamoraphan, 2018; Santos, 2017), and teaching instructions (Gilakjani, 2012; Hallin, 2014; Khaki et al., 2015; Olivosa et al., 2016). Given the role of cultural background, the findings of some researches ( $\mathrm{Wu}, 2010$; Sywelem et al., 2012) indicate different frequencies of learning style categories which are employed by learners in ESL or EFL contexts.

As the matter of fact, most learners have not thought about their learning style preferences, which are considered as a vital role in determining an individual's preferred way of learning. Though in Vietnam, English has gradually grown and expanded since the period from 1986 to the present (Hoang, 2010), studies on learners' learning style preferences have not been paid much attention and are kept marginalized. In other words, very few studies have been carried out to 
identify Vietnamese students' English learning style preferences. This study attempts to investigate Vietnamese students' English learning style preferences at the tertiary level using Reid's perceptual learning style model taking into consideration the following questions;

1. What are Vietnamese freshmen's English learning style preferences?

2. What is the correlation between learning style preferences and gender?

3. What is the hypothesis that there is no relationship between language learning styles and the English language achievement?

\section{Literature review}

\subsection{Definition of language learning style preferences}

Teaching methodology has undergone the shift from teacher-centered teaching approach to the state-of-art learner-centered teaching one which focuses on the role of learners in second language acquisition. Up to the present, the definition of language learning styles has attracted educational experts' and researchers' attention. In simple term, a learning style, also referred as cognitive style or cognitive strategy is a particular way of learning preferred by a learner. Different learners have their own ways in learning, and an activity which is accomplished by learners whose learning style prefers a visual mode of learning, may not be helpful or successful with a learner who favours auditory or kinesthetic modes of learning. Therefore, it is teacher's responsibility to recognize different learning styles among their learners because differences in learning styles are accounted for the way learners approach learning tasks, and the success of those tasks (Richards\& Schmidt, 2014).

The definition of language learning styles dates back to the late 1970s. Remarkably, Reid (1987) defines perceptual learning styles or interchangeably learning styles as the differences that learners use one or more senses to understand, organize, and retain experience. In another definition proposed by Dunn (1990), learning styles are defined as the way in which individuals begin to concentrate on, process, internalize, and retain new information. Kolb (1985) defines learning style as the generalized differences in learning orientation, so learning is regarded as the process whereby knowledge is accumulated through the transformation of experiences. Gregorc (1979) defines learning styles as "distinctive and observable behaviors that provide clues about the mediation abilities of individuals and how their minds relate to the world and, therefore, how they learn" (Gregorc, 1979, p. 19). Meanwhile, Fleming (2001) defines learning style as "an individual's characteristics and preferred ways of gathering, organizing, and thinking about information. VARK is in the category of instructional preference because it deals with perceptual modes. It is focused on the different ways that we take in and give out information" (Fleming, 2001, p. 1).

\subsection{Classification of language learning style models}

Different researchers share the similarities and dissimilarities in terms of the classification of language learning styles to some extent. Among the classifications, some language learning style models such as Reid (1995), Dunn and Dunn (1978/1992), Fleming (2001), Kolb (1985), Gregorc (1979), Felder and Silverman (1988) are widely recognized and accepted. 
Reid's perceptual learning styles (1995) were used as the back-up theory behind the current study. In his view, learning styles are classified into three main categories, namely personality learning styles, cognitive learning styles, and sensory learning styles. Based on learner's personality, personality learning styles can be divided into some learning styles such as extrovert, introvert, sensing, perception, thinking, feeling, judging, perceiving, ambiguity-tolerant, ambiguityintolerant, left-brained, and right-brained learners. Meanwhile, cognitive learning styles can be further split into field-independent and field-dependent, analytic and global, and reflective and impulsive. Finally, sensory learning styles can be classified into three main classifications, particularly personality learning styles, environmental learning styles, and perceptual learning styles. Basically, perceptual learning style preferences refer to the perceptual channels which students choose their own favoured ways of learning. According to Reid (1984), perceptual learning style preferences are categorized into auditory (involved in listening to lectures and radio recording), tactile (lab experiments, hand-on), visual (reading and studying diagrams), group (group work, share-study group), kinesthetic (relating to movement or physical activity), and individual learning (studying on own).

Another popular learning style model is widely acknowledged by Gregorc (1979), which focuses on phenomenological model. He asserts that individuals have natural predispositions for learning together with four bipolar, continuous mind qualities which function as mediators because individuals learn from and react to the surroundings. The model Gregorc (1979) suggested is also called Gregorc Style Delieator which includes four learning styles, namely concrete-sequential, abstract sequential, abstract random, and concrete random.

In line with Gregorc's (1979) learning style model, Kolb (1985) has a different approach basing on the experimental learning theory (hereafter ELT). ELT combines between a holistic model of the learning process and a multi-linear model of adult development. Kolb (1985) explains the terminology "experiential" for its intellectual source in the experimental work of Dewey's philosophical pragmatism, Piaget's cognitive-developmental genetic epistemology, and Lewin's social psychology, which shape a unique perspective on development and learning. Kolb's (1985) ELT comprises of four basic learning styles, namely diverger, assimilator, converger, and accommodator on a model with two dimensions. Diverger refers to a strong imaginative ability, good judgement from different perspectives, creativity, and good interpersonal skills. Meanwhile, assimilators yield theoretical models, encourage inductive reasoning, and work with abstract ideas. Converger, however, has a strong practical orientation, promote deductive thinking, and seem unemotional. Finally, accommodators involve in risk-taking activities, and dealing with problems intuitively.

Filder and Silverman (1988) introduced another learning/teaching style model which was originated in the engineering sciences. This model describes that individuals' learning style preferences are included in five bipolar continua such as the active-reflective, the sensing-intuitive, the verbal-visual, the sequentialglobal, and the intuitive-deductive. In particular, active learners enjoy working in 
groups while reflective learners need their own privacy to work individually to save time considering carefully the task before doing it. Sensing learners prefer data, figures, experimentation, and detailed work whereas intuitive learners would like theories and ideas, they especially like creating innovative and new initiatives. Verbal learners want to participate in discussions, to listen and express their opinions, meanwhile visual learners enjoy perceiving symbols, words, flow charts, or reading books. Finally, sequential learners like step-by-step procedures, linear reasoning, and systematic solutions, global learners are, in contrast, regarded as synthesizers and integrators, who like making intuitive discoveries and connections to grasp the whole system.

Dunn and Dunn (1992) propose a learning style model called the productivity environmental preference survey (PEPS). This model includes 5 learning style stimuli and sub-elements within each stimulus, i.e. environmental with its representative elements, namely temperature, room design, light, or sound; sociological (individual learning, pairwork with either peers or teachers, or both); physiological (chronological energy pattern, perceptual, mobility needs, and intake while learning); and psychological processing (hemisphericity, global or analytic, and impulsive or reflective). This model strengthens the role of individuals to find out, synthesize, and retain new information.

Fleming (2001) develops a sensory model which is referred to VARK model, standing for Visual, Aural, Read/write, and Kinesthetic. The four perceptual modes also have the differences among them. Visual learners prefer the intuitive representations, for example charts, flow charts, pictures, different spatial arrangements, etc. Aural learners, however, are dynamic because they like demonstrating themselves in actions such as topic discussion, group work, idea exchanges, retelling stories, and so on. Meanwhile, read/write learners tend to perceive receptiveness via textbooks, printed handouts, manuals, surfing the internet, or taking notes. Finally, kinesthetic learners prefer extroverted activities such as apprentice, laboratories, problem-solving, project-learning, field trips, or hand-on experiences. Thus, VARK model describes the perceptual modes that learners prefer using to give out information.

\subsection{Learning style preference with academic performance}

Learning involves developing various aspects of learners' progress and improvement in terms of self-efficacy, self-direction, self-regulation, self-control, autonomy, and intrinsic motivation. Academic performance, which is regarded as a directly observable indicator of learning, reflects the efficiency resulting from the mobilization of cognitive and emotional-volitional resources of learners doing certain task-based activities (Dobson, 2010; Yee et al., 2015; Hamdani, 2015; Almigbal, 2015; Moo \& Eamoraphan, 2018). Learners' performances refer to the level of obtained academic results, the qualititative and quantitative improvements in academic involvements. That is, it can be possibly predicted and explained students' learning performance thanks to a certain degree of probability such as known factors and ways that their effects are implemented (Magdalena, 2015). The prediction of students' academic performance includes the anticipation of certain results in learning. From pedagogical perspective, the success of 
academic performance accounts for the application and implementation of instructive actions (Hamdani, 2015; Khaki et al., 2015; Almigbal, 2015). Academic performance depends on the application and pedagogical practices by teachers on the interactions between strategies and educational goals (Ahmad, 2011; Komlosi, 2018; Muhtar, 2014; Li, 2012; Wong, 2015). Therefore, LSP plays an important role as a predictor of academic achievement and academic success default.

\subsection{Factors Affecting Language learning Style Preference}

The following factors greatly affect language learning styles to a certain extent. Different genders may have dissimilar views on LSP, learners' cultural differences might lead to different perceptions towards LSP. Moreover, LSP can be clearly recognized in second language acquisition.

\section{Gender}

Many researchers have investigated the relationship between LSP and gender. The hypothesis comes up with the assumption whether LSP is influenced by the gender. The research finding (Vaseghi et al., 2012; Bhattacharyya \& Sarip, 2014; Alkooheji \& Al-Hattami, 2018; Tawir \& Mustapha, 2017; Sarabi-Asiabar, 2014) indicates that gender differences in LSP actually exist among learners. According to Manova, cited by Vaseghi et al. (2012), students would rather receive more peer interaction than learn alone, and more kinesthetic activities. Congruent with Sarabi-Asiabar et al. (2014), their finding showed that using single model learning styles had a significant impact on gender in the way that female students would like to use aural learning style while male students preferred using the kinesthetic learning styles.

On the other hand, some research results (Ahmad, 2011; Bidabadi \& Yamat, 2010; Shuib \& Arizan, 2015; Tae-young\& Miso, 2018) indicated that gender is not affected by learning style preferences. For example, Ahmad (2011) investigated the role of gender towards the learning style preferences of 252 Low English Proficiency students at a local tertiary school. The result revealed that there was no influence of gender on students' learning style preferences. In another research conducted by Shuib and Azizan (2015) on learning style preferences among ESL students in Univesiti-Sains Malaysia, the finding shared the same view with Ahmad (2011) that students' learning preferences were not affected by gender.

\section{Cultural perspectives}

Another factor which can influence LSP is learners' cultural perspectives. Studies (Santos, 2017; Khanum, 2014; Shih, et al., 2013) have proved that it is important to get to know about the cultural perspectives in LSP. Investigating the English language learning style of the higher secondary learners in Bangladesh, Khanum (2014) stresses the importance of the cultural behavior in which he recommends. that teachers should incorporate culture-related style differences into the learning styles. Different cultural background may happen at a small educational setting or in different educational environments, cultural background to a certain extent influences language learners' learning style preferences (Santos, 2017). Furthermore, understanding cultural background could help learners avoid cultural shocks in cross-cultural tele-communication exchanges (Shih et al., 2013). Second Language Acquisition 
There are a number of studies examining the relationship between learning styles and second language acquisition. In the educational setting, the language knowledge intake of different learners can be the same in first language acquisition, however, when accumulating more languages, students could be influenced by their motivation to study as they could prefer visual, auditory or kinesthetic learning styles. On close investigation into English language learning, the adaptation of teaching methodology and course design are very necessary, this seems to be very challenging for teachers to adjust their teaching styles to match different learners in a classroom (Wong, 2015; Olivosa et al., 2016; Tee et al., 2015; Afshara et al., 2015; Komlosi, 2018; Khaki et al., 2015).

\subsection{Reid's Perceptual Learning Style Preference Questionnaire}

Perceptual learning style preference questionnaire (PLSPQ) is likened to and used as the main backbone of this study. This pilot study dealt with native English speakers and ESL students. The second pilot study, which was revised and improved in comparison with the first pilot one, was conducted with solely on ESL students in 1990. The questionnaire includes two parts, particularly the first part collects the interviewees' demographic information, while the second part explores the characteristics of learners based on 30 question items. These 30question items are divided into six types of learners: auditory, visual, kinesthetic, tactile, group and individual learners. In reality, there are many different learning style inventories introduced by many researchers. Take the learning style survey (LSS) introduced by Cohen, Oxford and Chi (2009) for example, there are 110 questions which cover the learners' perceptual and physical factors. Unlike the LSS, Reid's PLSPQ addresses learners' perceptual preferences in second language learning field. Renou (2011) claimed that Reid's PLSPQ was the first well known instrument to assess the learners' perceptual learning style preferences and it has been widely exploited in many other researches as well as this study.

\section{Method}

\subsection{Research design}

The study is basically designed to investigate the LSP of first-year students in Vietnam. The research backed up the quantitative method, using descriptive approach to give out the references for teaching and learning English at the tertiary level in Vietnam. The contact with university administrators for permission to carry out the survey questionnaire was initially done. Using Cochran's formula to determine the sample population, 385 participants were chosen through stratified sampling method. The respondents were asked to answer the questionnaire, including two parts, namely the demographic information and 30-adapted Reid's questionnaire items. The questionnaires, with a supporting letter from the university administrators, were sent to the participants through email attachment with the active link of Google form. The freshmen were requested to return the questionnaires after one week and in the case of a low response rate, another email served as a reminder would be sent to participants. The collected data went through the data screening before it was treated by IBM SPSS program for the purpose of data analysis in answering the 30-item question. 


\subsection{Research Instruments}

The study was used Reid's (1984) perceptual learning style questionnaire. The first part, which was designed by the author, identified respondents' demographic information such as sex, residence, learning English duration, and their groups. The second part adapted 30 items of Reid's (1984) PLSPQ, which masked into 6 categories examining four perceptual (auditory, visual, tactile, and kinesthetic), and two social (group, and individual) learning style preferences. The participants were expected to indicate (1) strong disagreement, (2) disagreement, (3) undecided choice, (4) agreement, and (5) strong agreement.

\subsection{Participants}

The respondents were selected as freshmen from 3 national and regional universities in Vietnam, namely the north - Vietnam National University, Hanoi; the central - Hue university; the south - Vietnam National University, Ho Chi Minh city. As clear explanation in the instruction, the target sample population was first-year students. Owing to unknown number of participants, Cochran's (1977) formula was used to determine the expected population, which was 385. In terms of gender participating in the study, the fewer number was 166 female students accounting for $43.1 \%$, whereas the majorrity of male students was 219 , equivalent to $56.9 \%$. When examining the freshmen's residence, over half of them camefrom rural areas with 195 first-year students or 50.6\%, then 117 students, making up $30.4 \%$ were from urban areas, and the rest population was from moutainous areas with the least propostion of $19.0 \%$, similar to 73 first-year students. As for the length of English learning experience, most of them spent fewer than 15 years studying English, namely $73 \%$ or 281 freshmen, then followed by lower $15.3 \%$ or 59 students who had fewer than 20 years of English education, and the least rank $11.7 \%$ or 45 learners had 10 years fewer acquiring English. On investigating students' groups, the majority of respondents was English nonmajor students with the proportion of $87.8 \%$, equivalent to 338 freshmen, whereas $12.2 \%$ or 47 English major students who did an intensive English course at their universities participating in the study.

\subsection{Procedures}

Having prepared the research instrument tools properly, the researcher had initial contacts with 3 national and regional university administrators to explain the purpose of the study and the assistance needed from the schools, and to seek permission for their students to participate the study in the second term of the school year 2019-2020. Once permission was granted, the questionnaire was sent to first-year students' email addresses provided by the universities concerned. The questionnaire, which was incorporated with the researcher's instruction, explained the objectives and relevance of the study, assured the anonymity, and gave them the option of not participating in the study if they wished. The respondents were requested to return the questionnaire after one week since the date of email-shot. A thanking email was sent back to the respondents as the confirmation of reception.

The researcher made a list of relevant questionnaires, then carried out the careful data screening process using the stratified sampling method to get the targeted number. Finally, the preset 385 samples were obtained, and the screened data 
were encoded for the purpose of the data treatment. The researcher used IBM SPSS program to analyze the questionnaire and the outputs of English proficiency test as well.

\subsection{Data Analysis}

The quantitative data was analyzed using descriptive statistics. Specially, frequency count, and percentage were employed to analyzed the demographic information such as sex, residence, length of English acquisition, and students' groups. Descriptive mean was treated to address 30 item PLSPQ to find out the legend of preferences in terms of 6 categories; auditory, visual, tactile, kinesthetic, social, and individual learning styles, together with determining Likert scales, particularly (1.0-1.79) very low, (1.8-2.59) low, (2.6-3.39) neutral, (3.4-4.19) high, and (4.2-5.0) very high. Independent-samples T Test was used to compare LSP and gender differences, among major and non-major English students with regard to LSP. One-way ANOVA was employed to test the correlation between LSP with students' English grade term to examine the relationship between LSP with firstyear students' English academic achievement.

\section{Results and discussion}

Table 1 presents two sources of information. That is, the discription of 6 kinds of learning style preferences, and the self-scoring intepretation.

Table 1: The interpretation of perceptual learning style preferences

\begin{tabular}{|c|c|c|c|c|c|c|}
\hline & & Z & $\sum_{\Sigma}^{\approx}$ & 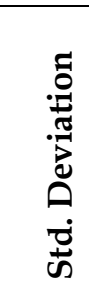 & 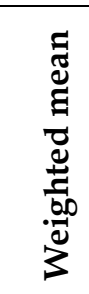 & 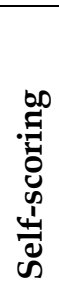 \\
\hline \multirow{5}{*}{$\frac{\pi}{5}$} & $\begin{array}{l}\text { I learn better by reading what the teacher writes on } \\
\text { the chalkboard. }\end{array}$ & 385 & 3.23 & .655 & \multirow{5}{*}{3.13} & \multirow{5}{*}{31} \\
\hline & When I read instructions, I remember them better. & 385 & 3.27 & .669 & & \\
\hline & I understand better when I read instructions. & 385 & 3.19 & .774 & & \\
\hline & $\begin{array}{l}\text { I learn better by reading than by listening to } \\
\text { someone. }\end{array}$ & 385 & 2.84 & .663 & & \\
\hline & $\begin{array}{l}\text { I learn more by reading textbooks than by listening } \\
\text { to lectures. }\end{array}$ & 385 & 3.13 & .664 & & \\
\hline \multirow{5}{*}{ 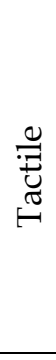 } & $\begin{array}{l}\text { I learn more when I can make a model of } \\
\text { something. }\end{array}$ & 385 & 3.94 & .612 & \multirow{5}{*}{4.08} & \multirow{5}{*}{41} \\
\hline & $\begin{array}{l}\text { I learn more when I make something for a class } \\
\text { project. }\end{array}$ & 385 & 4.12 & .710 & & \\
\hline & I learn better when I make drawings as I study. & 385 & 4.27 & .646 & & \\
\hline & $\begin{array}{l}\text { When I build something, I remember what I have } \\
\text { learned better. }\end{array}$ & 385 & 4.19 & .707 & & \\
\hline & I enjoy making something for a class project. & 385 & 3.90 & .594 & & \\
\hline \multirow{2}{*}{ 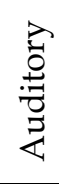 } & $\begin{array}{l}\text { When the teacher tells me the instructions I } \\
\text { understand better. }\end{array}$ & 385 & 4.09 & .622 & \multirow{2}{*}{3.76} & \multirow{2}{*}{38} \\
\hline & $\begin{array}{l}\text { When someone tells me how to do something in } \\
\text { class, I learn it better. }\end{array}$ & 385 & 3.66 & .740 & & \\
\hline
\end{tabular}




\begin{tabular}{|c|c|c|c|c|c|c|}
\hline & $\begin{array}{l}\text { I remember things I have heard in class better than } \\
\text { things I have read. }\end{array}$ & 385 & 3.06 & .730 & & \\
\hline & $\begin{array}{l}\text { I learn better in class when the teacher gives a } \\
\text { lecture. }\end{array}$ & 385 & 4.12 & .712 & & \\
\hline & I learn better in class when I listen to someone. & 385 & 3.89 & .651 & & \\
\hline \multirow{5}{*}{$\begin{array}{l}\text { Oे } \\
\text { రั) }\end{array}$} & I get more work done when I work with other. & 385 & 3.72 & .562 & \multirow{5}{*}{4.01} & \multirow{5}{*}{40} \\
\hline & I learn more when I study with a group. & 385 & 4.17 & .617 & & \\
\hline & In class, I learn best when I work with other. & 385 & 3.89 & .840 & & \\
\hline & $\begin{array}{l}\text { I enjoy working on an assignment with two or } \\
\text { three classmates. }\end{array}$ & 385 & 4.14 & .678 & & \\
\hline & I prefer to study with other. & 385 & 4.13 & .621 & & \\
\hline \multirow{5}{*}{ 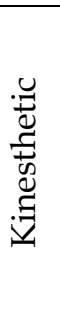 } & I prefer to learn by doing something in class. & 385 & 4.44 & .605 & \multirow{5}{*}{4.20} & \multirow{5}{*}{42} \\
\hline & When I do things in class, I learn better. & 385 & 4.06 & .655 & & \\
\hline & I enjoy learning in class by doing experiments. & 385 & 4.45 & .713 & & \\
\hline & $\begin{array}{l}\text { I understand things better in class when I } \\
\text { participate in role-playing. }\end{array}$ & 385 & 4.01 & .727 & & \\
\hline & $\begin{array}{l}\text { I learn best in class when I can participate in } \\
\text { related activities. }\end{array}$ & 385 & 4.05 & .645 & & \\
\hline \multirow{5}{*}{ 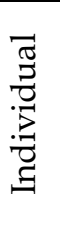 } & When I study alone, I remember things better. & 385 & 2.30 & .680 & \multirow{5}{*}{2.45} & \multirow{5}{*}{25} \\
\hline & \begin{tabular}{|l} 
When I work alone, I learn better. \\
\end{tabular} & 385 & 2.68 & .677 & & \\
\hline & In class, I work better when I work alone. & 385 & 2.49 & .700 & & \\
\hline & I prefer working on projects by myself. & 385 & 2.37 & .684 & & \\
\hline & I prefer to work by myself. & 385 & 2.43 & .574 & & \\
\hline \multirow[t]{2}{*}{ gend } & & \multirow{2}{*}{\multicolumn{2}{|c|}{$2.6-3.39$}} & \multirow{2}{*}{\multicolumn{2}{|c|}{ neutr }} & \\
\hline & $\begin{array}{l}1.0-1.79 \text { very low } \\
3.4-4.19 \text { high }\end{array}$ & & & & & \\
\hline
\end{tabular}

As glimpsed from Table 1, first-year students preferred reading instructions by themselves $(M=3.27 \%, S D=.669)$, succeeding this ranking, reading what the teacher wrote on the chalkboard $(M=3.23 \%, S D=.655)$, then reading instructions $(M=3.19 \%, S D=.774)$, surprisingly reading textbooks rather than listening lectures $(M=3.13 \%, S D=.664)$. The lowest figure in this category was the reading preference over listening to someone $(M=2.84 \%, S D=.663)$. In general, freshmen kept neutral opinions on Visual Learning Preference as the weighted mean of this group is 3.13, which reveals the fact that first-year students were unsure about their visual learning preference. Besides, the small standard deviation indicates that the respondents had slight differences in their viewpoints. Mean scores also supported the trend that first-year students preferred their autonomies in learning even though the weighted mean still belonged to the neutral scale accordingly. Basing on these figures, teachers should allow their students to be independent in their learning, schools and teachers should encourage their learners to actively involve the task-based learning and teaching or practical works instead of academic learning policies (Hamdani, 2015; Nge \& Eamoraphan, 2020).

In view of Tactile learning style in Table 1, this style refers to the opportunity for learners to do "hand-on" experiences with materials. The respondents developed the skills of mind map via drawings in studying $(M=4.27 \%$, SD = .646), freshmen needed to construct something to recall and review the previous knowledge $(M=$ $4.19 \%, S D=.707$ ). During the process of building something again, it is a good chance for them to exchange the knowledge, create something new, adjust the 
models, and mobilize the whole understanding from theory to practice (Olivosa at al., 2016; Svarcova \& Jelinkova, 2016; Yee et al., 2015). Participants confessed that they learnt more when involving in a class project $(M=4.12 \%, S D=.710)$. Tactile learners showed preferences for physical involvement relating to class activities (Magdalena, 2015; Dobson, 2010). Handling and building models are the remarkable characteristics of Tactile learners. When asked about this issue, the respondents remarked that they learnt better by making a model of something $(M$ $=3.94 \%)$. Tactile learners enjoyed making something for a class project $(M=3.90)$, this means that they were creative and would like to cooperate with other class members in terms of academic performances. In general, the participants had high preferences for Tactile learning style $(M=4.08)$, which is in line with other researches (Gilakjani, 2012; Marica et al., 2015; Santos, 2017).

When examining Auditory learning style, students showed high preferences as Tactile and Visual learning styles with the weighted means of 3.76. In particular, students confessed that their teachers' lectures helped them learn better $(M=4.12$, $S D=.712)$. Similarly, students supposed that they understood their teachers' instructions better $(M=4.09)$, and in such a situation that someone talking something in class enabled students to learn better $(M=3.89)$, which was clearly seen from Table 1. When instructed or explained how to do something during lessons, students could learn better $(M=3.66)$. However, students were unsure about the ability to remember things better in comparison to what they read ( $M=$ 3.06). From the data displayed in Table 1, the respondents indicated that they had no difficulty listening to teachers or classmates. Students believed that they could study and remember better when they were given instructions, lectures or something relating to the auditory means of communication. In other words, auditory medium in class could help students learn better which shared the similar findings in other studies (Alkooheji \& Al-Hattami, 2018; Tae-Young \& Miso, 2018; Gohar \& Sadeghi, 2014; Shih et al., 2013; Bidabadi \& Yamat, 2010).

Teamwork plays an important role at work. In terms of educational setting, group learning style is also necessary to be categorized and examined. As glimpsed from Table 1, studying with a group brought more positive result for students, who revealed that they could learn better $(M=4.17, S D=.617)$. Besides, students confirmed that working on an assignment in a group of two or three classmates encouraged them to do better $(M=4.14)$. This was somehow similar to the preference of studying with other classmates $(M=4.13)$. Nowadays, work-share is very common at workplace, so is learning. Students reckoned that they could learn best when cooperating with other class members $(M=3.89, S D=.840)$. In addition, freshmen asserted that they got more work done under the condition that they worked with other companions $(M=3.72, S D=.562)$. For this respective, first-year students did not have much differences in their viewpoints as the standard deviation was small $(S D=.562)$. On the whole, students had high preferences for the group learning style with the weighted mean of 4.01. As students highly prefer working and studying in groups, it is advisable for teachers to design cooperative assignments and classroom activities for students to do their best to learn more (Hallin, 2014; Khaki et al., 2015; Bhattacharyya \& Sarip, 2014; Tee et al., 2015; Wong, 2015). 
Kinesthetic learning style concentrates on the classroom experiences through actively participating in activities, problem-solving, field trips or role-playing in the classroom. When examining Kinesthetic learning style, freshmen showed very high preferences for it by calculating the weighted mean of 4.20 , which was clearly shown in Table 1. In more detail, doing experiments in class activated students most $(M=4.45 \%, S D=.713)$. Followed this rank, doing something in class was students' favour $(M=4.44 \%)$. Freshmen confirmed that they learnt better by doing things in class, which indicated that they wanted to be active learners $(M=4.06 \%)$. This confirmation was supported by another viewpoint that they learnt best through the involvement in related class activities $(M=4.05 \%, S D=.645)$. Besides, students revealed that role-playing in class helped them understand things better $(M=4.01 \%)$. The overall results of Kinesthetic learning style denote that students were active learners, they really wanted to participate and experience related class activities, students understood and accumulated the knowledge best. Therefore, the necessity of changing curriculum or teaching methodology is necessary to create active learning environments for students to do their utmost. Some research findings (Singh et al., 2015; Mulalic, et al., 2009; Ahmad, 2011; Bhattacharyya \& Sarip, 2014) recognized that the adaptation of curriculum and teaching methodology was needed to meet the demands of students.

Individual learning style stresses the important role of self-study individually. This style confirms that learners understand new material best when learning it alone. On investigating individual learning style, the results came out that students showed low preferences for it as the weighted mean was 2.45, which was clearly presented in Table 1 . In particular, students did not agree that they could learn better when working alone $(M=2.49 \%, S D=.677)$. Similarly, they disagreed that they could work better in class in case of working alone $(M=2.49 \%)$. Mentioning about working on projects alone, freshmen highly protested the opinion that they prefer to work by themselves $(M=2.37 \%)$. In addition, students claimed that they disliked working on their own $(M=2.43 \%)$, they also had a high similarity of choices as the standard deviation was quite small $(S D=.574)$. The respondents had a low favor for the statement that they could remember better when studying alone $(M=2.30 \%)$. In comparison with group learning style which had a high weighted mean, this style had a low one. When taking this opposite into careful consideration, the difference in preference between two styles is relevant. This finding has not been found in any other studies, for example Wong (2015), Lui (2017), Moo \& Eamoraphan (2018), Bidabadi \& Yamat (2010), Al-Zayed (2017), Khmakhien (2012), Marica et al. (2015), and so on.

As the explanation adapted from the C.I.T.E learning style instrument, Reid's PLSPQ is categorized into 6 kinds, i.e. Visual, Tactile, Auditory, Group, Kinesthetic, and Individual learning styles. The total conversion score of the whole PLSPQ is classified into 3 group preferences, namely (38-50) major LSP, (2537) minor LSP, and (0-24) negligible use. Major preference denotes any learning method coming natural, normal to the learners, while minor preference refers to learning ways which learners can perform adequately to meet the demands of the tasks. Negligible preference mentions any learning method that learners find it difficult to study with, they consequently will not choose it spontaneously 
(Psaltou-Joycey \& Kantaridou, 2011). By comparing between the results from Table 1 with 3 equivalent explanation preferences, the outcome goes that Visual and Individual learning styles belong to minor preferences whereas Kinesthetic, Group, Auditory, and Tactile learning preferences are grouped into major preferences. Table 2 presents the correlation between LSP and gender differences on the choice of language learning styles. The purpose of this comparison is to investigate whether there was a difference between male and female students in the choice of employing different language learning styles.

Table 2: The comparison between LSP and gender differences

\begin{tabular}{|c|c|c|c|c|c|c|c|c|c|c|}
\hline & \multicolumn{2}{|c|}{$\begin{array}{l}\text { Levene's } \\
\text { Test for } \\
\text { Equality of } \\
\text { Variances } \\
\end{array}$} & \multicolumn{7}{|c|}{ t-test for Equality of Means } \\
\hline & & \multirow[b]{2}{*}{$\mathrm{F}$} & \multirow[b]{2}{*}{ Sig. } & \multirow[b]{2}{*}{$\mathrm{t}$} & \multirow[b]{2}{*}{ df } & \multirow{2}{*}{$\begin{array}{l}\text { Sig. (2- } \\
\text { tailed) }\end{array}$} & \multirow{2}{*}{$\begin{array}{c}\text { Mean } \\
\text { Difference }\end{array}$} & \multirow{2}{*}{$\begin{array}{l}\text { Std. Error } \\
\text { Difference }\end{array}$} & \multicolumn{2}{|c|}{$\begin{array}{l}\text { 95\% Confidence } \\
\text { Interval of the } \\
\text { Difference }\end{array}$} \\
\hline & & & & & & & & & Lower & Upper \\
\hline \multirow{2}{*}{$\stackrel{7}{\frac{\pi}{2}}$} & $\begin{array}{l}\text { Equal } \\
\text { variances } \\
\text { assumed }\end{array}$ & .056 & .813 & .874 & 383 & .383 & .138 & .158 & -.173 & .449 \\
\hline & $\begin{array}{l}\text { Equal } \\
\text { variances } \\
\text { not } \\
\text { assumed }\end{array}$ & & & .870 & 349 & .385 & .138 & .159 & -.174 & .451 \\
\hline \multirow{2}{*}{ 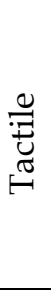 } & $\begin{array}{l}\text { Equal } \\
\text { variances } \\
\text { assumed } \\
\end{array}$ & .420 & .517 & .169 & 383 & .866 & .024 & .143 & -.258 & .306 \\
\hline & $\begin{array}{l}\text { Equal } \\
\text { variances } \\
\text { not } \\
\text { assumed }\end{array}$ & & & .169 & 352 & .866 & .024 & .144 & -.259 & .307 \\
\hline \multirow{2}{*}{ 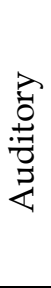 } & $\begin{array}{l}\text { Equal } \\
\text { variances } \\
\text { assumed } \\
\end{array}$ & 7.94 & .005 & -.67 & 383 & .505 & -.103 & .154 & -.405 & .200 \\
\hline & $\begin{array}{l}\text { Equal } \\
\text { variances } \\
\text { not } \\
\text { assumed }\end{array}$ & & & -.65 & 323 & .515 & -.103 & .157 & -.412 & .207 \\
\hline \multirow{2}{*}{ 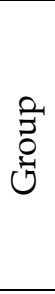 } & $\begin{array}{l}\text { Equal } \\
\text { variances } \\
\text { assumed } \\
\end{array}$ & 1.77 & .185 & -.44 & 383 & .658 & -.069 & .155 & -.374 & .236 \\
\hline & $\begin{array}{l}\text { Equal } \\
\text { variances } \\
\text { not } \\
\text { assumed }\end{array}$ & & & -.45 & 369 & .655 & -.069 & .153 & -.370 & .233 \\
\hline \multirow{2}{*}{ 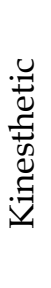 } & $\begin{array}{l}\text { Equal } \\
\text { variances } \\
\text { assumed } \\
\end{array}$ & 1.70 & .193 & -1.4 & 383 & .173 & -.213 & .156 & -.521 & .094 \\
\hline & $\begin{array}{l}\text { Equal } \\
\text { variances } \\
\text { not } \\
\text { assumed }\end{array}$ & & & -1.4 & 367 & .169 & -.213 & .155 & -.518 & .091 \\
\hline
\end{tabular}




\begin{tabular}{|c|c|c|c|c|c|c|c|c|c|c|}
\hline \multirow{2}{*}{ 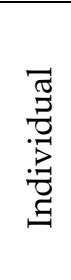 } & \begin{tabular}{|l} 
Equal \\
variances \\
assumed
\end{tabular} & .016 & .898 & -.14 & 383 & .891 & -.023 & .165 & -.347 & .302 \\
\hline & $\begin{array}{l}\text { Equal } \\
\text { variances } \\
\text { not } \\
\text { assumed }\end{array}$ & & & -.14 & 354 & .891 & -.023 & .165 & -.348 & .303 \\
\hline
\end{tabular}

As clearly seen from Table 2, the data reveal that the Sig. values of Levene's test for equality of variances of 6 learning styles are higher than the confidence level of $95 \%$, so the Sig. (2-tailed) values in the equal variances assumed would be used to take into account. Obviously, the Sig. (2-tailed) values turns out to be higher that the confidence level (.005), too. Based on these findings, the conclusion goes that male and female freshmen did not have differences on the choice of learning style preferences. This finding shares the similarity with other researches (Bhattacharyya \& Sarip, 2013; Shuib \& Azizan, 2015; Bidabadi \& Yamat, 2010; TaeYong \& Miso, 2018).

Table 3 contrasts the dissimilarity between major and non-major English students on the choice of language learning styles. It is clearly presented in the Sig. values of Levene's test for equality of variances that the Sig. values of 6 language learning styles are higher than the confidence level (0.05), which leads to the decision on choosing the Sig. (2-tailed) values of the equal variances assumed. Similarly, the Sig. (2-tailed) values of 6 learning styles get higher than the confidence level (0.05). Therefore, from two sources of the data - Sig. and Sig. (2 tailed), it is concluded that there was no difference between major and non-major English students in terms of choosing language learning styles. This contrastive analysis has not been popular in the field of LSP as few studies have been conducted on the comparison among major and non-major English learners and language learning style preferences.

Table 3: The comparison between major and non-major English students

\begin{tabular}{|c|c|c|c|c|c|c|c|c|c|c|}
\hline & \multicolumn{2}{|c|}{$\begin{array}{l}\text { Levene's } \\
\text { Test for } \\
\text { Equality } \\
\text { of } \\
\text { Variances }\end{array}$} & \multicolumn{7}{|c|}{ t-test for Equality of Means } \\
\hline & & \multirow[b]{2}{*}{$\mathrm{F}$} & \multirow[b]{2}{*}{ Sig. } & \multirow[b]{2}{*}{$\mathrm{t}$} & \multirow[b]{2}{*}{ df } & \multirow{2}{*}{$\begin{array}{l}\text { Sig. (2- } \\
\text { tailed) }\end{array}$} & \multirow{2}{*}{$\begin{array}{l}\text { Mean } \\
\text { Difference }\end{array}$} & \multirow{2}{*}{$\begin{array}{l}\text { Std. Error } \\
\text { Difference }\end{array}$} & \multicolumn{2}{|c|}{$\begin{array}{c}95 \% \text { Confidence Interval } \\
\text { of the Difference }\end{array}$} \\
\hline & & & & & & & & & Lower & Upper \\
\hline $\bar{\sigma}$ & \begin{tabular}{|l} 
Equal \\
variances \\
assumed
\end{tabular} & 1.4 & .24 & -.11 & 383 & .909 & -.027 & .239 & -.498 & .443 \\
\hline$\stackrel{\overrightarrow{7}}{>}$ & \begin{tabular}{|l} 
Equal \\
variances \\
not \\
assumed
\end{tabular} & & & -.10 & 57.3 & .915 & -.027 & .256 & -.540 & .485 \\
\hline 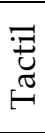 & \begin{tabular}{|l} 
Equal \\
variances \\
assumed
\end{tabular} & .356 & .55 & .78 & 383 & .436 & .169 & .217 & \begin{tabular}{|c|}
-257 \\
\end{tabular} & .595 \\
\hline
\end{tabular}




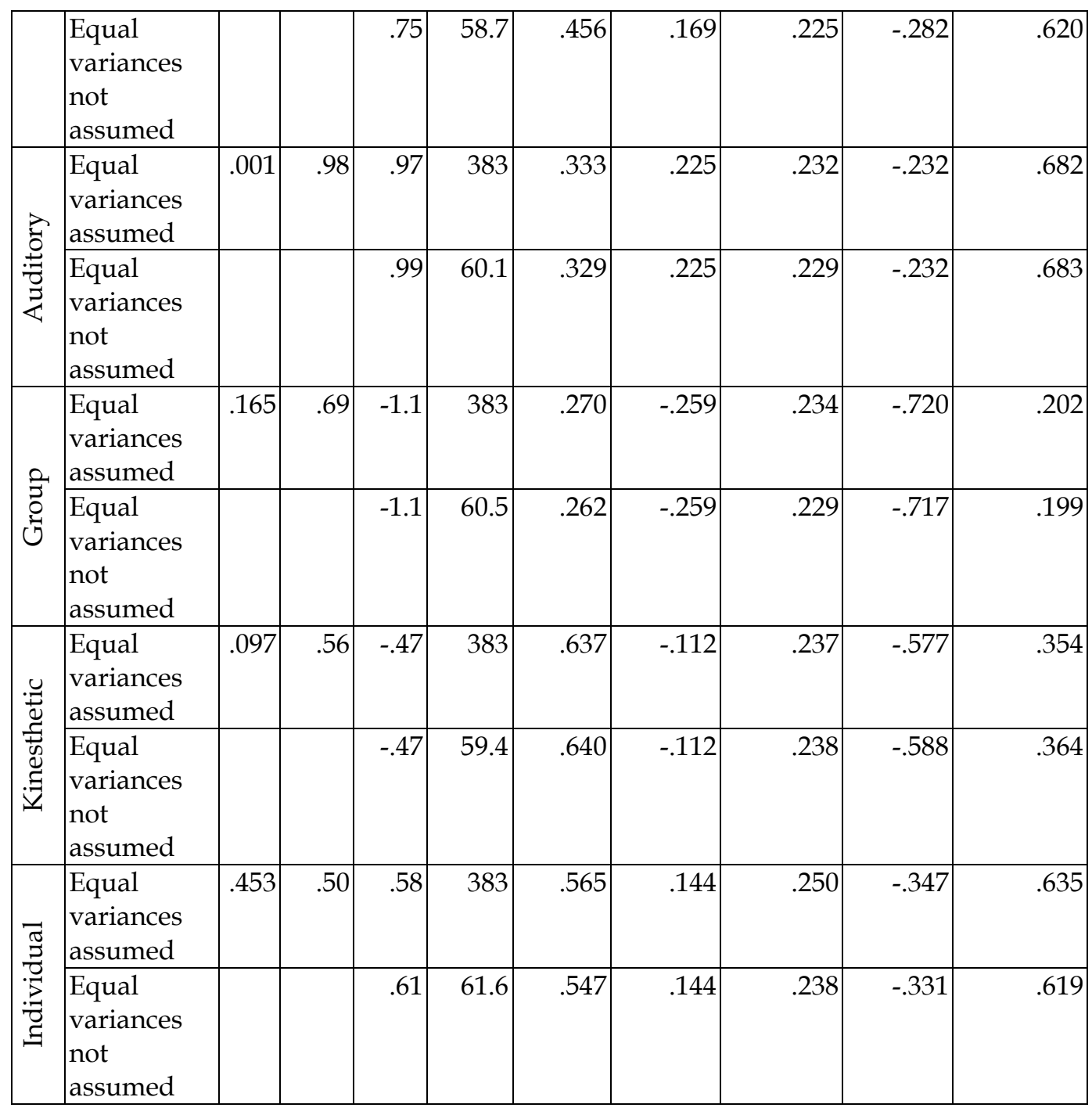

A far as the relationship between LSP and student academic achievement is concerned, the following data is obtained. Table 4 addresses the hypothesis that there is no relationship between LSP and English academic achievement. As seen in Table 4, Sig. values of 6 learning style are higher than the preset confidence level (0.05). That means the results reject the hypothesis and denote that LSP, to a certain extent, influences English academic achievement. The influence of LSP on English academic achievement reflects the students' preferences as they are classified into major and minor learners as shown in Table 1 . That is, freshmen are active language learners, which might somehow affect English academic achievement. Some researches (Fang-Mei, 2013; Khmakhien, 2012; Gohar \& Sadeghi, 2014; Tabatabaeia \& Mashayekhi, 2013) have shared the similar results as this study. 
Table 4: The relationship between LSP and English grade term ANOVA

\begin{tabular}{|c|c|c|c|c|c|c|}
\hline & $\begin{array}{l}\text { Sum of } \\
\text { Squares }\end{array}$ & df & $\begin{array}{c}\text { Mean } \\
\text { Square }\end{array}$ & F & Sig. \\
\hline \multirow[t]{3}{*}{ Visual } & $\begin{array}{l}\text { Between } \\
\text { Groups }\end{array}$ & 6.12 & 6 & 1.02 & .429 & .860 \\
\hline & $\begin{array}{l}\text { Within } \\
\text { Groups }\end{array}$ & 899.98 & 378 & 2.38 & & \\
\hline & Total & 906.10 & 384 & & & \\
\hline \multirow[t]{3}{*}{ Tactile } & $\begin{array}{l}\text { Between } \\
\text { Groups }\end{array}$ & 30.07 & 6 & 5.01 & 2.65 & .016 \\
\hline & $\begin{array}{l}\text { Within } \\
\text { Groups }\end{array}$ & 714.07 & 378 & 1.89 & & \\
\hline & Total & 744.14 & 384 & & & \\
\hline \multirow[t]{3}{*}{ Auditory } & $\begin{array}{l}\text { Between } \\
\text { Groups }\end{array}$ & 10.21 & 6 & 1.70 & .760 & .602 \\
\hline & $\begin{array}{l}\text { Within } \\
\text { Groups }\end{array}$ & 845.79 & 378 & 2.24 & & \\
\hline & Total & 855.99 & 384 & & & \\
\hline \multirow[t]{3}{*}{ Group } & $\begin{array}{l}\text { Between } \\
\text { Groups }\end{array}$ & 16.84 & 6 & 2.81 & 1.24 & .284 \\
\hline & $\begin{array}{l}\text { Within } \\
\text { Groups }\end{array}$ & 853.91 & 378 & 2.26 & & \\
\hline & Total & 870.74 & 384 & & & \\
\hline \multirow[t]{3}{*}{ Kinesthetic } & $\begin{array}{l}\text { Between } \\
\text { Groups }\end{array}$ & 13.31 & 6 & 2.22 & .960 & .452 \\
\hline & $\begin{array}{l}\text { Within } \\
\text { Groups }\end{array}$ & 873.67 & 378 & 2.31 & & \\
\hline & Total & 886.96 & 384 & & & \\
\hline \multirow[t]{3}{*}{ Individual } & $\begin{array}{l}\text { Between } \\
\text { Groups }\end{array}$ & 7.13 & 6 & 1.19 & .458 & .839 \\
\hline & $\begin{array}{l}\text { Within } \\
\text { Groups }\end{array}$ & 980.14 & 378 & 2.59 & & \\
\hline & Total & 987.26 & 384 & & & \\
\hline
\end{tabular}

\section{Pedagogical implications}

It is important for teachers to understand students' learning styles. Teachers are advisable to change the curriculum or teaching styles to meet the students' expectations. In hope to do so, teachers should carry out the survey to find out students' learning styles, thanks to the results of the survey, teachers will have relevant pedagogical activities to help students do their best to achieve the highest English learning outcome. Besides, first-year students can modify and adjust their learning styles so that they can adapt themselves to meet the requirements of instructions, contexts, tasks or related English learning activities. Table 5 summarizes the learning strategies (Oxford, 1990) and recommended teaching activities which are in accordance with the styles they belong to. 
Table 5: Proposed combination of language learning strategies and teaching activities matching the learning style preferences.

\begin{tabular}{|c|c|c|}
\hline \begin{tabular}{l|l} 
& Language learning strategies \\
Major/minor learning styles
\end{tabular} & Language learning strategies & Teaching activities \\
\hline \multicolumn{3}{|c|}{ Major/minor learning styles } \\
\hline Visual & $\begin{array}{l}\text { Memory: visualizing mental } \\
\text { images Cognitive: identifying } \\
\text { different colours } \\
\text { Metacognitive: making up goals } \\
\text { and objectives }\end{array}$ & $\begin{array}{l}\text { Extensive reading, written } \\
\text { instructions, using outlines, } \\
\text { flash cards, TV, videos, internet }\end{array}$ \\
\hline Hands-on & $\begin{array}{l}\text { Compensation: mimes and } \\
\text { gestures } \\
\text { Memory: using physical response } \\
\text { Social: cooperating with others }\end{array}$ & $\begin{array}{l}\text { Making posters, collages, } \\
\text { activities that allow students to } \\
\text { move around, change groups } \\
\text { frequently, projects, CALL, role } \\
\text { playing, activities that make } \\
\text { authentic use of the language, } \\
\text { jigsaw. }\end{array}$ \\
\hline Extroverted & $\begin{array}{l}\text { Social: cooperating with } \\
\text { peers/proficient users, asking for } \\
\text { clarification } \\
\text { Metacognitive: organise own } \\
\text { learning, seeking practice } \\
\text { opportunities (mainly out of } \\
\text { class) } \\
\text { Do not use affective strategies. Do } \\
\text { not favour solitary/concentrated } \\
\text { study. } \\
\text { More indirect strategies than } \\
\text { direct ones. }\end{array}$ & $\begin{array}{l}\text { Discussions/debates, role } \\
\text { playing, cooperative tasks, } \\
\text { question-generating activities, } \\
\text { activities that make students act } \\
\text { physically. }\end{array}$ \\
\hline $\begin{array}{l}\text { Intuitive- } \\
\text { random }\end{array}$ & $\begin{array}{l}\text { Memory: associating, elaborating } \\
\text { Compensation strategies: } \\
\text { guessing from context } \\
\text { Metacognitive: planning } \\
\text { Cognitive: analysing and } \\
\text { reasoning } \\
\text { Social strategies: asking questions } \\
\text { Affective: (limited use): lowering } \\
\text { anxiety, encouraging oneself }\end{array}$ & $\begin{array}{l}\text { Brainstorming, naturalistic } \\
\text { input, applying rules to new } \\
\text { situations, synthesis of } \\
\text { information from randomly } \\
\text { selected sources, inference tasks, } \\
\text { tasks offering change and } \\
\text { variety, skip around a text }\end{array}$ \\
\hline $\begin{array}{l}\text { Concrete- } \\
\text { sequential }\end{array}$ & $\begin{array}{l}\text { Cognitive: practising } \\
\text { Memory: imagery, employing } \\
\text { action, structured reviewing, rote } \\
\text { memorisation } \\
\text { Metacognitive: arranging and } \\
\text { planning }\end{array}$ & $\begin{array}{l}\text { Activities with clear } \\
\text { instructions, synthesis of } \\
\text { information from carefully } \\
\text { selected sources, well-planned } \\
\text { homework, drawings, } \\
\text { kinesthetic input }\end{array}$ \\
\hline $\begin{array}{l}\text { Closure- } \\
\text { oriented }\end{array}$ & $\begin{array}{l}\text { Memory: associating/elaborating, } \\
\text { structured reviewing } \\
\text { Metacognitive: arranging and } \\
\text { planning, evaluating, goal-setting } \\
\text { with deadlines, overviewing and } \\
\text { linking with previous material } \\
\text { Cognitive: practising (formal, } \\
\text { drill-like) } \\
\text { Social: asking for correction, } \\
\text { clarification }\end{array}$ & $\begin{array}{l}\text { Activities that have a clear goal, } \\
\text { tasks that follow a predictable } \\
\text { sequence to get a sense of } \\
\text { organisation }\end{array}$ \\
\hline
\end{tabular}




\begin{tabular}{|c|c|c|}
\hline Global & $\begin{array}{l}\text { Memory: semantic mapping, } \\
\text { grouping, } \\
\text { Cognitive: skimming, } \\
\text { summarising, analysing } \\
\text { contrastively } \\
\text { Compensation: guessing } \\
\text { Social: cultural understanding }\end{array}$ & $\begin{array}{l}\text { Mind-maps, inductive tasks, } \\
\text { finding } \\
\text { similarities/differences/main } \\
\text { idea, open-ended questions, } \\
\text { extensive reading, discussions, } \\
\text { learning through experiential } \\
\text { tasks }\end{array}$ \\
\hline \multicolumn{3}{|c|}{ Negligible learning styles } \\
\hline Auditory & $\begin{array}{l}\text { Memory: representing sound in } \\
\text { memory } \\
\text { Cognitive: note-taking from } \\
\text { auditory input } \\
\text { Social strategies: asking questions }\end{array}$ & $\begin{array}{l}\text { Reading aloud, discussions, } \\
\text { group work, using songs, music }\end{array}$ \\
\hline Open & $\begin{array}{l}\text { Cognitive: recombining, } \\
\text { analysing, getting the idea } \\
\text { quickly, practising naturalistically } \\
\text { Metacognitive: seeking practice } \\
\text { opportunities } \\
\text { Compensation: guessing } \\
\text { Social: cooperating } \\
\text { Affective: Using humour to lower } \\
\text { anxiety, rewarding oneself }\end{array}$ & $\begin{array}{l}\text { Discovery learning, activities } \\
\text { involving risk taking, } \\
\text { entertainment, cooperation }\end{array}$ \\
\hline Analytic & $\begin{array}{l}\text { Cognitive: scanning, practising, } \\
\text { analysing contrastively, reasoning } \\
\text { deductively } \\
\text { Metacognitive strategies: } \\
\text { centering one's learning }\end{array}$ & $\begin{array}{l}\text { Drawing flowcharts with } \\
\text { linkage of ideas, taking detailed } \\
\text { notes, deductive tasks, } \\
\text { dissecting vocabulary } \\
\text { (suffixes/prefixes), drilling } \\
\text { exercises }\end{array}$ \\
\hline Introverted & $\begin{array}{l}\text { Metacognitive (generally } \\
\text { preferred): planning for a } \\
\text { language task, careful } \\
\text { organisation of learning, } \\
\text { Cognitive: analysing and } \\
\text { reasoning (formal strategies) } \\
\text { Affective/ social (generally } \\
\text { rejected) Self-encouragement }\end{array}$ & $\begin{array}{l}\text { Individual tasks/work, } \\
\text { cooperative tasks or pair work } \\
\text { with familiar/ } \\
\text { trusted classmate in stress free } \\
\text { environment, } \\
\text { CALL }\end{array}$ \\
\hline
\end{tabular}

\section{Limitations and Recommendations for Future Research}

This study has not done a pilot study to see how effective the realization and application of known learning styles of students in teaching and learning English. The future research should undertake a quasi-experimental study to find out the effects of recognizing students' learning styles in reality. By the way, more researches should be done with more students' scales, not only limited to the three national and regional universities. If possible, there should be researches conducted to compare and contrast between students' English learning preferences and English teachers' teaching styles.

\section{Conclusion}

This study aimed to identify the relationship between perceptual learning style preferences of Vietnamese university freshmen with English academic achievement. The pupose of the study is that learning styles are regarded as the 
affective factors contributing to be students's success in English aquisition. In Vietnamese educational system, the expected learning outcomes of English competence at the tertiary level is clearly set by 6 levels of foreign language competency (MOET, 2014), based on the Common European Framework of Reference for languages (CEFR). The circular states that non-major university leavers have to meet the requirement of $\mathrm{B} 1$ (CEFR) while major students have to pass C1 (CEFR). That is why investigating LSP would improve the fruit of learning and teaching English at the tertiary level.

Based on the classification of the perceptual learning styles which is categorized by Reid (1984), Vietnamese univesity freshmen are generally regarded as active learners. Among 6 learning styles, first-year universitty students are determined as major learning styles with regard to Tactile, Auditory, Group, and Kinesthetic learners, whereas they are also classified as minor learning styles in reference to Visual and Individual learners. Regarding the gender differences on the choice of learning styles, no significant difference is recognized between male and female freshmen in terms of employing learning styles. Moreover, the disparity between their decision on choosing learning styles is very small. This study is considered as one of the pioneer investigation conducted on the different perceptions of major and non-major English freshmen on the choice of language learning styles. The result indicates that major and non-major English students do not have different opinions on choosing their learning styles. Findings on the impact of students' learning style preferences on their academic achievement indicate that language learning styles somehow influences on students' English competency. As such, this conclusion is also supported by the fact that first-year students are categorized into major and minor language learning style preferences.

\section{Acknowledgments}

The authors would like to express their deepest gratitude and sincere appreciation to blind reviewers and the editors who encouraged, assisted and gave him constructive feedback to shape up this paper.

\section{Funding information}

This article is financially supported by Hanoi Law University.

\section{Declaration of Conflicting Interests}

The author declared no potential conflicts of interest with respect to the research, authorship, and/or publication of this article.

\section{References}

Afshara, H. S., Sohrabib, S., \& Mohammadib, R. M. (2015). On the Relationship among Iranian ESP Learners' Learning Strategy Use, Learning Styles and their English LanguageAchievement. Procedia - Social and Behavioral Sciences, 192, 724-729. http:/ /dx.doi.org/10.1016/j.sbspro.2015.06.079

Ahmad, A. A. (2011). Language Learning Style Preferences of Low English Proficiency (LEP) Students in a Tertiary Institution. Malaysian Journal of ELT Research (MaJER), $7(2), \quad 33-62 . \quad$ Retrieved from https://journals.melta.org.my/index.php/majer/article/view/158/73 
Ajideh, P., Zohrabi, M., \& Pouralvar, K. (2018). Investigating the Relationship between Learning Styles and ESP Reading Strategies in Academic Setting. International Journal of Applied Linguistics \& English Literature, 7(3), 156-164. http://dx.doi.org/10.7575/aiac.ijalel.v.7n.3p.156

Almigbal, T. H. (2015). Relationship between the Learning Style Preferences of Medical Students and Academic Achievement. Saudi Medical Journal, 36(3), 349-355. http://dx.doi.org/10.15537/smj.2015.3.10320

Al-Zayed, N. (2017). An Investigation of Learning Style Preferences on the Students' Academic Achievements of English. International Journal of English Linguistics, 7(5), 176-183. http://dx.doi.org/10.5539/ijel.v7n5p176

Alkooheji, L., \& Al-Hattami, A. (2018). Learning Style Preferences among College Students. International Education Studies, 11(10), 50-63. http://dx.doi.org/10.5539/ies.v11n10p50

Bidabadi, F. S., \& Yamat, H. (2010). Learning Style Preferences by Iranian EFL Freshman University Students. Procedia Social and Behavioral Sciences, 7, 219-226. http:/ / dx.doi.org/10.1016/j.sbspro.2010.10.031

Bhattacharyya, E., \& Sarip, A. B. M. (2014). Learning Style and Its Impact in Higher Education and Human Capital Needs. Procedia - Social and Behavioral Sciences, 123, 485-494. http://dx.doi.org/10.1016/j.sbspro.2014.01.1448

Bogamuwa, I. N. J. (2017). Learning Style Preferences of English as Second Language Learners in the Open University English for General Academic Purpose (EGAP) Programme. Retrieved from http://www.ou.ac.lk/ours/wp-content/uploads/2017/04/HS0201-F.pdf

Cohen, D. A., Oxford, L. R., \& Chi, C. J. (2009). Learning Style Survey: Assessing Your Own Learning Styles. Maximizing study abroad: An instructional guide to strategies for language and culture learning and use, 153-161. Retrieved from https://carla.umn.edu/maxsa/documents/LearningStyleSurvey_MAXSA.pdf

Cochran, W. G. (1977). Sampling Techniques (3rd ed). John Wiley \& Sons, New York.

Choudhary, R., Dullo, P., \& Tandon, R. V. (2011). Gender Differences in Learning Style Preferences of First Year Medical Students. Pak J Physiol, 7(2), 42-45. Retrieved from http://pps.org.pk/PJP/7-2/Raghuveer.pdf

Dobson, J. L. (2010). A comparison between learning style preferences and sex, status, and course performance. Adv Physiol Educ., 34(4), 197-204. http://dx.doi.org/10.1152/advan.00078.2010

Dunn, R., \& Dunn, K. (1978). Teaching students through their individual learning styles. Reston, VA: Reston.

Dunn, R., \& Dunn, K. (1992). Teaching secondary students through their individual learning styles. Needham Heights, MA: Allyn and Bacon.

Dunn, R. (1990). Understanding the Dunn and Dunn learning style model and the need for individual diagnosis and prescription. Journal of Reading, Writing, and Learning $\begin{array}{llll}\text { Disabilities } & \text { International, } & 6(3), & 223-\end{array}$ http://dx.doi.org/10.1080/0748763900060303

Fang-Mei, T. (2013). Adult EFL Students' Preferred Learning Styles and Motivation. The Journal of Human Resource and Adult Learning, 9(2), 161-171. Retrieved from http:/ / www.hraljournal.com/Page/16\%20Fang-Mei\%20Tai.pdf

Felder, R. M., \& Silverman, L. K. (1988). Learning styles and teaching styles in engineering education. Engineering Education, 78(7), 674- 681.

Fleming, N. (2001). Teaching and learning styles: VARK strategies. Christchurch, New Zealand: N.D. Fleming. 
Furnham, A., \& Monsen, J. (2009). Personality traits and intelligence predict academic school grades. Learning and Individual Differences, 19(1), 28-33. http://dx.doi.org/10.1016/j.lindif.2008.02.001

Gilakjani, A. P. (2012). A Match or Mismatch Between Learning Styles of the Learners and Teaching Styles of the Teachers. I.J.Modern Education and Computer Science, 11, 5160. http:/ /dx.doi.org/10.5815/ijmecs.2012.11.05

Gohar, M. J., \& Sadeghi, N. (2014). The Impact of Learning Style Preferences on Foreign language Achievement: A Case Study of Iranian EFL Students. Procedia-Social and Behavioral Sciences, 171, 754-764. http://dx.doi.org/10.1016/j.sbspro.2015.01.188

Gregorc, A. F. (1979). Learning/teaching styles: Their nature and effects. In J. W. Keefe (Ed.), Student learning styles: Diagnosing and prescribing programs (pp. 19-26). Reston, VA: National Association of Secondary School Principals.

Hallin, K. (2014). Nursing students at a university - A study about learning style preferences. Nurse Education Today, 34(12), 1443-1449. http://dx.doi.org/10.1016/j.nedt.2014.04.001

Hamdani, D. A. (2015). Exploring Students' Learning Style at a Gulf University: A Contributing Factor to Effective Instruction. Procedia-Social and Behavioral Sciences, 176, 124-128. http://dx.doi.org/10.1016/j.sbspro.2015.01.452

Hoang, V. V. (2010b). The Current Situation and Issues of the Teaching of English in Vietnam. Ritsumeikan Studies in Language and Culture, 22(1), 7-18. Retrieved from http://www.ritsumei.ac.jp/acd/re/k-rsc/lcs/kiyou/pdf_221/RitsIILCS_22.1pp.7-18_HOANG.pdf

Khaki, N., Ganjabi, M., \& Khodamoradi, A. (2015). The Effect of Learning Style on the Performance of Students in a Preemptive Focus-on-Form Instruction. Retrieved from http://www.ugr.es/ portalin/articulos/PL_numero24/2NASRIN.pdf

Khanum, F. (2014). Learners' Learning Style Preferences and Teachers' Awareness in the Context of Higher Secondary Level in Bangladesh. Global Journal of Human-Social Science: Arts \& Humanities-Psychology, 14(10). Retrieved from https://globaljournals.org/GJHSS_Volume14/1-Learners-Learning-StylePreferences.pdf

Khmakhien, A. (2012). Demystifying Thai EFL learners' perceptual learning style preferences. 3L: Language, Linguistics, Literature, 18(1), 61-74. Retrieved from https://core.ac.uk/reader/11493020

Kolb, D. (1985). Learning style inventory (revised edition) Boston: McBer.

Komlosi, F. (2018). Bulgarian University Students' Learning Style Preferences in ESL Classrooms. Journal of Language and Education, 4(2), 30-47. http:/ / dx.doi.org/10.17323/2411-7390-2018-4-2-30-4

Li, C. (2012). An Investigation of Chinese Students' Learning Styles at an English-medium University in Mainland China. Theory and Practice in Language Studies, 2(1), 6-13. http://dx.doi.org/10.4304/tpls.2.1.6-13

Lui, C. J. (2017). The Perceptual Learning Style Preferences of Hispanic Students in Higher Education. (Doctoral Dissertation, Brigham Young University). Retrieved from https:// scholarsarchive.byu.edu/cgi/ viewcontent.cgi?article=7712\&context=etd

Magdalena, S. M. (2015). The Relationship of Learning Styles, Learning Behaviour and Learning Outcomes at the Romanian Students. Procedia - Social and Behavioral Sciences, 180, 1667-1672. http://dx.doi.org/10.1016/j.sbspro.2015.05.062

Marica, M., Pengerb, S., Todorovicc, I., Djuricac, N., \& Pintara, R. (2015). Differences in Learning Styles: A comparison of Slovenian Universities. Procedia - Social and Behavioral Sciences, 197, 175-183. http://dx.doi.org/10.1016/j.sbspro.2015.07.079 
MOET (2014). Circular No. 01/2014 /TT-BGDĐT of the Ministry of Education and Training: Promulgating a 6-level foreign language competence framework for Vietnam. Retrieved from

http://vanban.chinhphu.vn/portal/page/portal/chinhphu/hethongvanban?clas s_id=1\&_page $=3 \&$ mode $=$ detail $\&$ document_id $=172297$

Moo, M., \& Eamoraphan, S. (2018). A Correlational-Comparative Study of Students' Perceptual Learning Style Preferences in Learning English as a Foreign Language and Their Academic Achievement in the Cetana Academic Program for English at Myanmar Institute of Theology, 10(2). Retrieved from http://www.assumptionjournal.au.edu/index.php/Scholar/article/view/3588

Muhtar, S. N. (2014). A Study of Learning Style Preferences of All Female Students in University Level. ELTIN, Journal of English Language Teaching in Indonesia, 2(1), 3546. http://dx.doi.org/10.22460/eltin.v2i1.p\%25p

Mulalic, A., Shah, P. M., \& Ahmad, F. (2009). Learning-style preference of ESL students. AJTLHE: ASEAN Journal of Teaching and Learning in Higher Education, 1(2), 9-17. Retrieved from http://journalarticle.ukm.my/1485/

Nge, N. R. \& Eamoraphan, S. (2020). A Comparative Study of Students' Perceptual Learning Style Preferences and Their Academic Achievement in Learning English as a Foreign Language at Nelson English Language Centre, Myanmar. Scholar: Human Sciences, 12(1), 181-193. Retrieved from http://www.assumptionjournal.au.edu/index.php/Scholar/article/view/3593

Olivosa, P., Santos, A., Martín, S., Canas, M., Gómez-Lázaro, E., \& Maya, Y. (2016). The relationship between learning styles and motivation to transfer of learning in a vocational training programme. Suma Psicológica, 23, 25-32. http://dx.doi.org/10.1016/j.sumpsi.2016.02.001

Oxford, R. L. (1989). Use of language learning strategies: A synthesis of studies with implications for strategy training. System, 17(2), 235-247. http://dx.doi.org/10.1016/0346-251X(89)90036-5

Oxford, R. L. (1990). Language Learning Strategies: What Every Teacher Should Know. Boston, Massachusetts: Heinle \& Heinle.

Psaltou-Joycey, A., \& Kantaridou, Z. (2011). Major, minor, and negative learning style preferences of university students. System, 39(1), 103 - 112. http://dx.doi.org/10.1016/j.system.2011.01.008

Reid, J. M. (1984). Perceptual Learning Styles Preference Questionnaire. Copyrighted.

Reid, J. M. (1987). The learning style preferences of ESL students. TESOL Quarterly. 21(1), 87-111. Retrieved from http://old.fltrp.com/download/06071807.pdf

Reid, J. M. (1995). Learning styles in the ESL/EFL classroom. Florence, KY: Heinle \& Heinle

Renou, J. (2011). A study of perceptual learning styles and achievement in a university-level foreign language course. Retrieved from http://crisolenguas.uprrp.edu/Articles/JanetRenou.pdf

Richards, J. C., \& Schmidt, R. W. (2014). Longman dictionary of language teaching and applied linguistics (4th ed., pp. 331-332). London: Routledge, Taylor \& Francis Group.

Sadeghi, N., Kasim, Z. M., Tan, B. H., \& Abdullah, F. S. (2012). Learning Styles, Personality Types and Reading Comprehension Performance. English Language Teaching, 5(4), 116-123. http://dx.doi.org/10.5539/elt.v5n4p116

Sarabi-Asiabar, A., Jafari, M., Sadeghifar, J., Tofighi, S., Zaboli, R., Peyman, H., Salimi, M., \& Shams, L. (2014). The relationship between learning style preferences and gender, educational major and status in first year medical students: A survey study from Iran. Iranian Red Crescent medical journal, 17(1). http://dx.doi.org/10.5812/ircmj.18250 
Santos, H. T. D. (2017). Learning Style Preferences and their Relationship to Second Language Acquisition in Students of English as a Second Language. (Doctoral Dissertation, Auburn University). Retrieved from https:/ / etd.auburn.edu/handle/10415/5667

Shih, Y. D., Liu, Y., \& Sanchez, C. (2013). Online Learning Style Preferences: An analysis on Taiwanese and USA Learners. The Turkish Online Journal of Educational Technology, 12(4), 140-152. $\quad$ Retrieved from http:/ / www.tojet.net/articles/v12i4/12416.pdf

Shuib, M., \& Azizan, S. N. (2015). Learning Style Preferences among Male and Female ESL Students in Universiti-Sains Malaysia. Journal of Educators Online, 12(2), 103-141. Retrieved from https://eric.ed.gov/?id=EJ1068392

Sims, R. R., Veres, J. G., \& Shake, L. G. (1989). An Exploratory Examination of the Convergence between the Learning Styles Questionnaire and the Learning Style Inventory II. Educational and Psychological Measurement, 49(1), 227-233. http:/ /dx.doi.org/10.1177/0013164489491025

Singh, L., Govil, P, \& Rani, R. (2015). Learning Style Preferences among Secondary School Students. International Journal of Recent Scientific Research, 6(5), 3924-3928. Retrieved from http://www.recentscientific.com/sites/default/ files/2411.pdf

Stevenson, J., \& Dunn, R. (2001). Knowledge management and learning styles: prescriptions for future teachers. College Student Journal, 35(4), 483-490.

Svarcova, E., \& Jelınkova, K. (2016). Detection of Learning Styles in the Focus Group. Procedia - Social and Behavioral Sciences, 217, 177-182. http://dx.doi.org/10.1016/j.sbspro.2016.02.057

Sywelem, M., Al-Harbi, Q., \& Fathema, N. (2012). Learning Style Preferences of Student Teachers: A Cross-Cultural Perspective. Institute for Learning Styles Journal, 1, 10-24. https://eric.ed.gov/?id=ED533031

Tabatabaeia, O., \& Mashayekhi, S. (2013). The relationship between EFL learners' learning styles and their L2 achievement. Procedia - Social and Behavioral Sciences, 70, 245-253. http:/ / dx.doi.org/10.1016/j.sbspro.2013.01.061

Tae-Young, K., \& Miso, K. (2018). Relationships among perceptual learning style, the ideal L2 self, and motivated L2 behavior in college language learners. Porta Linguarum, 30, 7-22. Retrieved from https://dialnet.unirioja.es/servlet/articulo?codigo=6691571

Tawir, K. M. O., \& Mustapha, S. M. (2017). Learning styles preference, gender and English language performance of EFL Libyan secondary school students in Malaysia. Infrastructure University Kuala Lumpur Research Journal, 5(1), 50-62. Retrieved from https://iukl.edu.my/rmc/wp-content/uploads/sites/4/2019/01/6.-KhalidMuktar.pdf

Tee, T. K., Yunos, J. M., Kuppusamy, B., Yee, M. H., Mohamad, M. M., Othman, W., CheRus, R., \& Hanapi, Z. (2015). The Pattern of Learning Styles among Second Year Students in Business Management and Hospitality Programs at One of The Vocational College in Northern Zone. Procedia - Social and Behavioral Sciences, 204, 62-72. http://dx.doi.org/10.1016/j.sbspro.2015.08.110

Wilson, M. L. (2012). Students' Learning Style Preferences and Teachers' Instructional Strategies: Correlations Between Matched Styles and Academic Achievement. Srate Journal, 22(1), 36-44. Retrieved from https://files.eric.ed.gov/fulltext/EJ995172.pdf

Wong, W. L. H. (2015). A Study of Language Learning Style and Teaching Style Preferences of Hong Kong Community College Students and Teachers in English for AcademicPurposes (EAP) Contexts. (Doctoral Dissertation, University of Canterbury). Retrieved from http://hdl.handle.net/10092/11661 
Wu, M. M. (2010). An Exploratory Study of the Language-learning Style Preferences and Language-learning Motivation of ESL Learners at a Vocational Education Institute in Hong Kong. Electronic Journal of Foreign Language Teaching, 7(2), 222-238. Retrieved from https://e-flt.nus.edu.sg/v7n22010/wu.pdf

Vaseghi, R., Ramezani, A. E., \& Gholami, R. (2012). Language Learning Style Preferences: A Theoretical and Empirical Study. Advances in Asian Social Science (AASS), 2(2), 441-451.

Yee, M. H., Yunos, J. M., Othman, W., Hassan, R., Tee, T. K., \& Mohamad, M. M. (2015). Disparity of Learning Styles and Higher Order Thinking Skills among Technical Students. Procedia-Social and Behavioral Sciences, 204, 143-152. http://dx.doi.org/10.1016/j.sbspro.2015.08.127 